\title{
Solid organ donation from the emergency department - A systematic review
}

\author{
Jessica McCallum, MD*; Brittany Ellis, MD, MSc*; Sonny Dhanani, MD; Ian G. Stiell, MD, MSc ${ }^{\ddagger}$
}

\section{CLINICIAN'S CAPSULE}

What is known about the topic?

There is an organ donor shortage. End-of-life care discussions occur in the emergency department (ED), therefore there may be opportunities for donation.

What did this study ask?

What percentage of successful and missed adult organ donors come from the ED?

What did this study find?

This systematic review found that the ED is a significant source of both successful and missed organ donors.

Why does this study matter to clinicians?

ED healthcare providers should know their local organ donation referral protocol to ensure that donors are not missed.

\section{ABSTRACT}

Objectives: A significant gap exists between people awaiting an organ transplant and organ donors. The purpose of this study was to determine what percent of successful donors come from the emergency department (ED), whether there are any missed donors, and to identify factors associated with successful and missed donation.

Methods: This systematic review used electronic searches of EMBASE, MEDLINE, and CINAHL according to PRISMA guidelines on July 7, 2017. We included primary literature in adults describing successful and missed organ donation. Two authors independently screened articles, and discrepancies were resolved through consensus. Quality was assessed using the STROBE checklist.

Results: This systematic review identified 1,058 articles, and 25 articles were included. For neurologic determination of death, ED patients comprised $4 \%-50 \%$ of successful donors and $3.6 \%-8.9 \%$ of successful donors for donation after circulatory determination of death. ED death reviews revealed up to $84 \%$ of missed neurologic determination of death, and $46.2 \%$ of missed circulatory determination of death donors who died in the ED are missed due to a failure to refer for consideration of organ donation. Clinical heterogeneity precluded pooling of the data to conduct a meta-analysis.

Conclusions: The ED is a source of actual and missed donors. Potential donors are often missed due to incorrect assumptions regarding eligibility criteria and failure of the healthcare team to refer for consideration of donation. ED healthcare professionals should be aware of organ donation referral protocols at their institution to ensure that no organ donors are missed.

\section{RÉSUMÉ}

Objectif: II existe un écart important entre le nombre de malades dans l'attente d'une transplantation d'organe et celui de donneurs d'organes. L'étude avait donc pour but de déterminer le pourcentage de donneurs effectifs qui proviennent du service des urgences (SU), le risque de non-repérage des donneurs potentiels et les facteurs associés aux dons effectifs ou manqués d'organes.

Méthode: Une revue systématique consistant en une recherche électronique dans les bases de données EMBASE, MEDLINE et CINAHL a été menée selon les lignes directrices PRISMA, le 7 juillet 2017. Ont été retenus des articles de première main faisant étant du repérage ou non des donneurs potentiels d'organes chez les adultes. Deux auteurs ont examiné, chacun de leur côté, les articles, et les divergences de points de vue ont été résolues par voie de consensus. La qualité des études a été évaluée à l'aide de la liste de vérification STROBE.

Résultats: La revue systématique a permis de dégager 1058 articles, dont 25 ont été retenus. Les patients au SU représentaient de 4 à $50 \%$ des donneurs effectifs en ce qui concerne les cas de mort cérébrale, et de 3,6 à 8,9\% des donneurs effectifs en ce qui concerne les cas de mort cardiocirculatoire. D'après l'examen des causes de décès au $\mathrm{SU}$, le taux de non-repérage des donneurs potentiels pouvait atteindre $84 \%$ dans les cas de mort cérébrale et $46,2 \%$ dans les cas de mort cardiocirculatoire, la situation s'expliquant par le manque de consultations des ressources en dons éventuels d'organes. Enfin, il n'a pas été possible de procéder à une méta-analyse en raison de l'hétérogénéité des données cliniques qui faisait obstacle à leur mise en commun.

From the *Department of Emergency Medicine, University of Ottawa, Ottawa, ON; †Division of Critical Care, Department of Pediatrics, University of Ottawa, Ottawa, ON; and ¥Department of Emergency Medicine, Ottawa Hospital Research Institute, University of Ottawa, Ottawa, ON.

Correspondence to: Dr. Jessica McCallum, Department of Emergency Medicine, 1053 Carling Avenue, Ottawa, ON K1Y 4E9; Email: j.harrismccallum@ gmail.com

(C) Canadian Association of Emergency Physicians 
Conclusion: Le SU est une source à la fois effective et non identifiée de donneurs d'organes. Souvent, les donneurs potentiels ne sont pas repérés en raison d'une perception erronée des critères d'admissibilité et du manque de consultations, par l'équipe de soins, des ressources en dons éventuels d'organes. Les professionnels de la santé au SU devraient donc être bien informés des protocoles de consultation des ressources en la matière dans leur établissement afin d'éviter le non-repérage des donneurs potentiels.

Keywords: Brain death, circulatory death, organ donation, systematic review

\section{INTRODUCTION}

There is a significant gap between the number of people waiting for an organ and organ donors. In 2018, in Ontario, there were 1,639 people awaiting organ donation, 456 decreased donors, and 947 organs transplanted from deceased donors. ${ }^{1}$ In BC, in 2018, there were 669 people on the transplant wait list, and 27 people died while on the wait list. ${ }^{2}$ Although progress has been made in organ donation in Canada, a significant gap between organ donors and people awaiting organ transplantation still exists; therefore, further efforts are required to ensure that all potential organ donors are identified.

Many end-of-life care discussions occur in the ED. ${ }^{3}$ Witjes et al. (2017) found that, in $51 \%$ of the time, the decision to start end-of-life care was made in the ED. ${ }^{3}$ One study suggested that $60.5 \%$ of family interviews for potential brain dead donors occurred in the ED. ${ }^{4}$ Another study showed that of all successful organ donors, $6 / 14(27.3 \%)$ had the organ donor discussion initiated in the ED. ${ }^{5}$ Furthermore, two studies have shown that patients referred from the ED are more likely to become successful donors than those referred from elsewhere in the hospital. ${ }^{6,7}$ These studies highlight the role the ED has in ensuring that potential donors are not missed.

Previous systematic reviews have investigated organ donation from the intensive care unit (ICU) exclusively, or pooled organ donation from the ED and ICU together. ${ }^{8-10}$ There may be ED-specific factors that could impact organ donation. The purpose of this study is to determine what percent of successful donors come from the ED, whether there are any missed or potential donors, and what factors impact organ donation in the ED.

\section{METHODS}

\section{Data sources and search strategy}

We conducted this systematic review according to preferred reporting items for systematic reviews and meta-analyses (PRISMA) guidelines. ${ }^{11,12}$ A medical librarian performed electronic searches of EMBASE, MEDLINE, and CINAHL on July 7, 2017. Duplicates were electronically removed during the search. Additional duplicates were removed manually during screening.

Our search strategy used Medical Subject Headings $(\mathrm{MeSH})$ terms and free words in the title and abstract by combining terms in two categories. One category included terms related to organ donation such as "tissue and organ procurement," "donor* or donat"," "nonheart-beating," and "brain death." The other category was related to the types of injuries or terms related to emergency medicine. Terms included "wounds and injuries," "trauma," "brain hemorrhage," "gunshot wound," "ED or emergency room or emergency service or emergency medicine or emergency care or emergency hospital." The full search strategy can be found in Appendix I.

Studies were included if they met the following criteria (Figure 1). Primary literature on adult (age $\geq 18$ years) humans was included if they investigated organ donation and reported either number of actual donors, missed donors, or potential donors. Papers were excluded if they were case reports, not organ donation, outcomes not reported (technique for organ removal, organ donor criteria, factors affecting organ viability, determination of death, recipient-specific data, survey of attitudes, curriculum to increase donation, process of consent), not solid organ donation (living donor, forensic donation), tissue donor (skin, bone marrow, cornea, blood, stem cell, science, sperm), and ethical considerations. For the title and abstract screen, all papers reporting either number of actual, missed, or potential organ donors were included, regardless of the location in the hospital. The full paper was then screened for ED-specific data. If it was unclear whether data reported was ED-specific, authors were contacted to confirm whether there were ED-specific data. If there were no ED-specific data, the paper was excluded according to "ED data not reported." The full text papers were also 


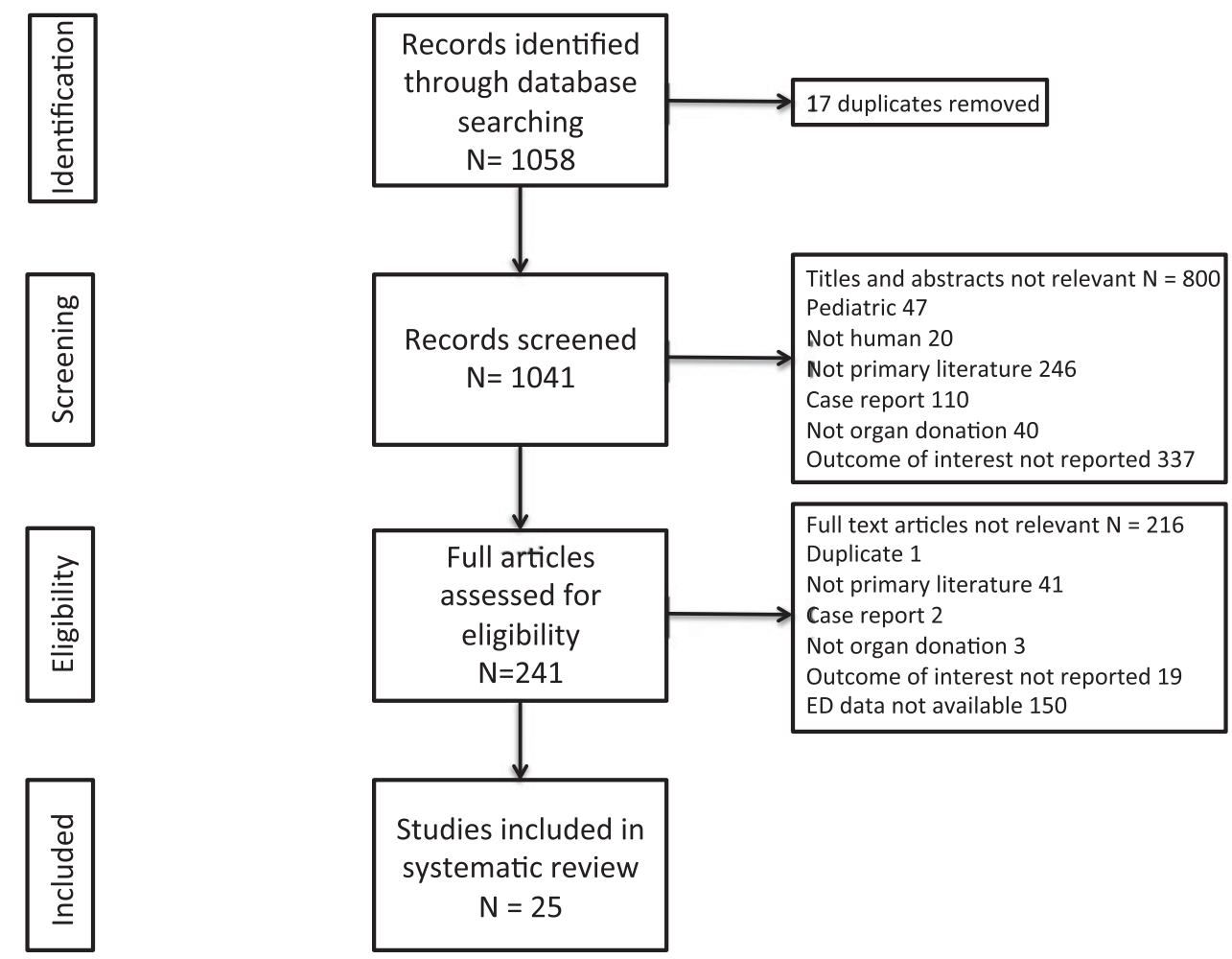

Figure 1. PRISMA flow diagram.

screened for data such that a percentage could be calculated. If papers only reported number of organ donors in the ED without reporting total number of actual or potential donors, the paper was excluded as "outcomes not reported." The reference list of all included papers was reviewed for additional papers.

Two reviewers (JM, BE) independently screened papers for inclusion according to the criteria outlined previously, using Microsoft Excel $^{\odot}$. Discrepancies were resolved by consensus.

\section{Data abstraction and quality assessment}

Data were abstracted from papers into an Excel database. If data were missing, authors were contacted. Data were abstracted for study design, population, and outcomes. Outcomes included percentage of successful organ donors coming from the ED and percentage of missed or potential donors in the ED (Tables 1-5). Papers were separated by neurologic determination of death and donation after circulatory determination of death. Donors were separated into these two populations, because screening criteria are different. In neurologic determination of death, the patient is declared as brain dead and in donation after circulatory determination of death the heart and blood circulation stop. ${ }^{13}$ In controlled donation after circulatory determination of death, circulatory death occurs in an expected setting, often after withdrawal of life support, whereas in uncontrolled donation after circulatory determination of death, death occurs in the out-of-hospital setting or after an unsuccessful resuscitation. ${ }^{13}$

Studies were assessed for quality using the Strengthening the Reporting of Observational Studies in Epidemiology (STROBE) checklist,${ }^{14}$ and missing elements are highlighted in Tables 1-4.

\section{Data synthesis and analysis}

There was significant clinical heterogeneity between included papers regarding organ donor population. Heterogeneity existed regarding study design (prospective, retrospective, and convenience sample) and patient population (hospital-wide v. ED, trauma v. all-comers). Similarly, the majority of the studies did not specify organ donor exclusion and inclusion criteria. This precluded pooling of the studies to perform a meta-analysis. 


\section{Table 1. Summary of papers for successful neurologic determination of death donors}

\begin{tabular}{|c|c|c|c|c|}
\hline Paper & Design & Population & Outcomes & $\begin{array}{l}\text { STROBE } \\
\text { checklist }\end{array}$ \\
\hline $\begin{array}{l}\text { Witjes et al. } \\
\qquad(2017)\end{array}$ & $\begin{array}{l}\text { Prospective } \\
\text { observational study } \\
\text { of } 7 \text { hospitals January } \\
2013 \text { - April } 2014\end{array}$ & $\begin{array}{l}\text { All adult patients dying } \\
\text { of devastating brain } \\
\text { injury in hospital }\end{array}$ & $7 / 54$ successful donors (13\%) came from ED* & Complete \\
\hline $\begin{array}{l}\text { Miller et al. } \\
\text { (2014) }\end{array}$ & $\begin{array}{l}\text { Retrospective cohort } \\
\text { analysis of } 81 \\
\text { hospitals from July } 1 \\
2007 \text { - June } 30,2012\end{array}$ & $\begin{array}{l}\text { All patients referred to } \\
\text { organ procurement } \\
\text { organization for } \\
\text { consideration of brain } \\
\text { death (trauma and } \\
\text { non-trauma) }\end{array}$ & $\begin{array}{l}243 \text { organ donors referred from the ED, } 7,194 \text { form the ICU } \\
\text { Patients referred for evaluation from the ED more likely to become donors than patients } \\
\text { referred from the Intensive Care Unit }(19.3 \% \text { v. } 5.2 \%, p=0.01) \\
\text { Total organs per donor higher in ED patients } 3.79 \text { v. } 3.16, p=0.24 \\
\text { Total donors } 47(E D)+373(I C U)=420 \\
47 / 420(11 \%) \text { came from ED }\end{array}$ & Complete \\
\hline $\begin{array}{l}\text { Summers } \\
\text { et al. } \\
\text { (2014) }\end{array}$ & $\begin{array}{l}\text { Prospective audit of all } \\
\text { deaths in the UK from } \\
\text { April } 2010- \\
\text { December } 2011 \\
\text { grouped into } 9 \\
\text { different zones }\end{array}$ & $\begin{array}{l}\text { All patients who died in a } \\
\text { critical care setting } \\
\text { Successful kidney } \\
\text { donors (NDD and DCD) }\end{array}$ & $\begin{array}{l}\text { Factors considered within the multifactorial model in a forward step-wise fashion were: age, } \\
\text { cause of death, ethnicity, and type of critical care in which the death took place. } \\
1528(5.6 \%) \text { of patients who died and became kidney donors } \\
3050 / 27,482(11 \%) \text { of deaths were in the ED } \\
67 / 1528(4 \%) \text { successful donors died in ED } \\
43 / 984(4 \%) \text { NDD donors } \\
24 / 544(4 \%) \text { DCD donors }\end{array}$ & Complete \\
\hline $\begin{array}{l}\text { Michael } \\
\text { et al. } \\
\text { (2009) }\end{array}$ & $\begin{array}{l}\text { Retrospective single } \\
\text { center cohort study } \\
\text { January 1, 2005- } \\
\text { September 30, } 2008\end{array}$ & $\begin{array}{l}\text { All solid organ donor } \\
\text { referrals for brain } \\
\text { death } \\
\text { Logistic regression of } \\
\text { ED v. inpatient organ } \\
\text { donors }\end{array}$ & $\begin{array}{l}\text { 6,886 donor referrals } \\
\text { Bivariate analysis: successful organ donation associated with younger age, mechanism of } \\
\text { injury (CNS injury), referral from ED, Caucasian race } \\
\text { Multiple logistic regression showed referral from ED significantly associated with referral } \mathrm{OR}= \\
1.52,95 \% \mathrm{Cl}=1.18 \text { to } 1.97) \text {, age }(\mathrm{OR}=0.96,95 \% \mathrm{Cl}=0.96 \text { to } 0.97) \text {, and mechanism of } \\
\text { injury ( } p<0.001 \text { ) } \\
\text { Patients from ED more likely to have consent granted compared to inpatient settings ( } 66.5 \% \\
\text { V. } 57.3 \% \mathrm{OR}=1.37,95 \% \mathrm{Cl}=0.93 \text { to } 2.02, p=0.12 \text {, ED donors } 111 \text {, inpatient } 355 \text { ) } \\
\text { ED donors } 111 / 466(24 \%)\end{array}$ & Complete \\
\hline $\begin{array}{c}\text { Ergin et al. } \\
(2008)\end{array}$ & $\begin{array}{l}\text { Prospective single site } \\
\text { early } 2006, \text { exact } \\
\text { dates not reported }\end{array}$ & $\begin{array}{l}\text { Death audit of all dying } \\
\text { patients }\end{array}$ & $\begin{array}{l}19 \text { patients potential donors in hospital } \\
6 \text { from ED ( } 4 \text { became real donors), } 5 \text { pediatric ED, } 6 \text { neurosurgical ICU, } 2 \text { external centers } \\
9 \text { donors yielding } 16 \text { kidneys, } 3 \text { hearts, } 5 \text { cadaveric valves, } 9 \text { livers, } 18 \text { corneas } \\
\text { ED donors } 4 \text { / } 9 \text { ( } 44 \% \text { ) }\end{array}$ & $\begin{array}{l}\text { Exact dates of } \\
\text { study not } \\
\text { specified }\end{array}$ \\
\hline $\begin{array}{l}\text { Tenn-Lyn } \\
\text { et al. } \\
\text { (2006) }\end{array}$ & $\begin{array}{l}\text { Retrospective cohort } \\
\text { study using } \\
\text { convenience sample } \\
\text { of } 8 \text { Ontario } \\
\text { neurosurgical }\end{array}$ & $\begin{array}{l}\text { Patients sent for } \\
\text { neurosurgical } \\
\text { assessment }\end{array}$ & $\begin{array}{l}141 \text { reviewed } \\
14(9.9 \%) \text { successful organ donors, } 2(14 \%) \text { died in ED, } 12 \text { (8.5\%) died following admission } \\
\text { Of } 86 \text { patients who died, } 22(25.6 \%) \text { had organ donation discussed } \\
6(27.3 \%) \text { had discussion initiated in ED }\end{array}$ & $\begin{array}{l}\text { Convenience } \\
\text { sample } \\
\text { increases risk } \\
\text { of selection } \\
\text { bias } \\
\text { (Continued }\end{array}$ \\
\hline
\end{tabular}




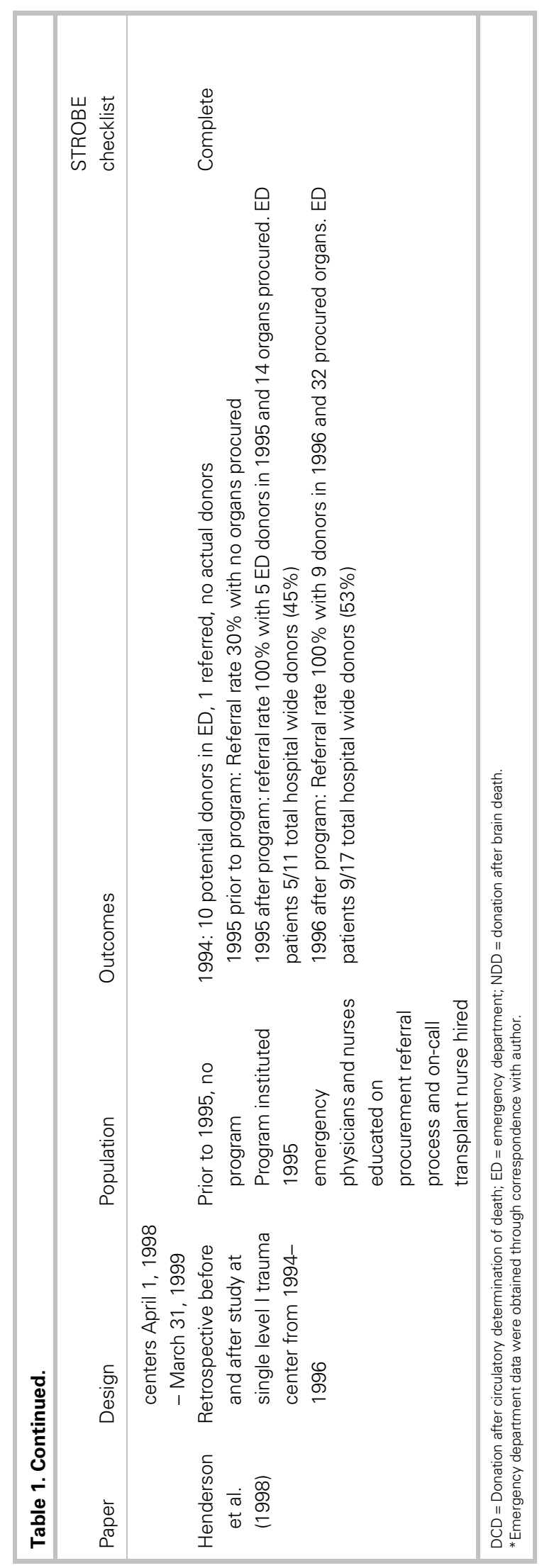

Descriptive data from individual studies are shown in Tables 1-5.

For the purpose of this systematic review, the definition of ED donor varies depending on the study design. In studies of successful organ donation, an ED donor is a donor that was referred to an organ procurement organization from the ED or had brain death declared in the ED. For the death reviews of missed and potential donors, an ED donor is a patient who died in the ED.

\section{RESULTS}

\section{Search results}

Our search results yielded 1,058 studies (see Figure 1). An additional 17 duplicates were removed, yielding 1,041 individual titles and abstracts to screen. Articles totalling 800 were excluded based on title and abstract, yielding 241 full articles to assess for eligibility. Full-text articles totalling 216 were excluded, yielding 25 articles that were included in the systematic review.

\section{Neurologic determination of death}

There were seven papers that reported successful organ donation from ED patients after neurologic determination of death. ${ }^{3,5-7,15-17}$ In these studies, patients were referred for consideration of organ donation while they were in the ED. All seven studies mentioned the role of the ED in referring donors to an organ procurement organization or involvement of an organ donation coordinator to facilitate donation. Taken together, these seven studies suggest that the $4 \%-50 \%$ of successful organ donors come from the ED. A summary of successful neurologic determination of death papers can be found in Table 1 .

There were five death reviews that investigated actual missed organ donors who died in the ED that were missed as a result of a failure to refer for consideration of organ donation. ${ }^{3,18-21}$ Two of these studies determined that of all actual missed donors in the hospital, $13 \%-80.9 \%$ died in the ED. ${ }^{3,18}$ One study found that $84 \%$ of donors dying in the ED were missed. ${ }^{19}$ Two studies found that $0 \%-2 \%$ of brain dead patients dying in the ED are missed. In all cases, these donors were missed due to a failure to refer. A summary of these papers can be found in Table 2 . 
Table 2. Summary of papers for missed and potential neurologic determination of death donors

\begin{tabular}{|c|c|c|c|c|}
\hline Paper & Design & Population & Outcomes & STROBE checklist \\
\hline $\begin{array}{l}\text { Witjes et al. } \\
(2017)^{*}\end{array}$ & $\begin{array}{l}\text { Prospective observational } \\
\text { study of } 7 \text { hospitals } \\
\text { January } 2013 \text { - April } 2014\end{array}$ & $\begin{array}{l}\text { All adult patients dying of } \\
\text { devastating brain injury in } \\
\text { hospital }\end{array}$ & $\begin{array}{l}72 \text { unrecognized potential donors in hospital } 9 / 72(13 \%) \text { died in ED } \\
\text { In } 51 \% \text { of cases decision to start end of life care made in ED }\end{array}$ & Complete \\
\hline $\begin{array}{l}\text { Broomberg } \\
\text { et al. } \\
(2005)\end{array}$ & $\begin{array}{l}\text { Prospective study at a single } \\
\text { teaching hospital March } \\
2003 \text { - June } 2003\end{array}$ & $\begin{array}{l}\text { Death audit of all brain deaths in } \\
\text { trauma unit, ED, ICU }\end{array}$ & $\begin{array}{l}\text { 13/76 in emergency unit with head injury, } 6 \text { patients arrested, } 6 \text { patients put } \\
\text { on ventilator but not referred, } 1 \text { brain dead and referred } \\
\text { Missed rate in ED } 0 \%\end{array}$ & Complete \\
\hline $\begin{array}{l}\text { Riker et al. } \\
\text { (1991) }\end{array}$ & $\begin{array}{l}\text { Retrospective death review at } \\
\text { Level I trauma center over } \\
14 \text { months }\end{array}$ & $\begin{array}{l}\text { Potential brain dead patients dying } \\
\text { in the ED or referred from the ED } \\
\text { to the OR, or Radiology }\end{array}$ & $\begin{array}{l}155 \text { charts reviewed } \\
99 \text { potential cornea donors } \\
61 \text { potential heart valve donors } \\
3 \text { potential kidney donors } \\
130 / 155(84 \%) \text { reviewed made no mention of organ donation }\end{array}$ & Complete \\
\hline $\begin{array}{l}\text { Garside } \\
\text { et al. } \\
\text { (2012) }\end{array}$ & $\begin{array}{l}\text { Retrospective single center } \\
\text { cohort study March } 2008- \\
\text { August } 2010\end{array}$ & $\begin{array}{l}\text { Before and after study of the effect } \\
\text { of a collaborative care pathway } \\
\text { of brain death patients in the } \\
\text { Emergency Department } \\
\text { Death review }\end{array}$ & $\begin{array}{l}\text { Referrals significantly increased from } 3 / 151 \text { eligible patients }(2 \%) \text { to } 26 / 160 \\
\text { patients }(16 \%), p<0.001 \\
\text { Number of successful organ donors increased from } 0-2 \\
\text { Missed rate } 84 \%\end{array}$ & Complete \\
\hline $\begin{array}{l}\text { Kim et al. } \\
\qquad(2000)\end{array}$ & $\begin{array}{l}\text { Retrospective review May } \\
1997 \text { - October } 1997\end{array}$ & $\begin{array}{l}\text { Death review of all potential brain } \\
\text { death donors for renal } \\
\text { transplantation }\end{array}$ & $\begin{array}{l}718 \text { deaths reviewed } \\
324(45 \%) \text { died in the ED } \\
35(8.9 \%) \text { acceptable potential donors in ICU and } 3(0.9 \%) \text { potential donors } \\
\text { in the ED } \\
\text { ED donors } 3 \text { / } 38(8 \%)\end{array}$ & Complete \\
\hline $\begin{array}{l}\text { Andres } \\
\text { et al. } \\
\text { (1999) }\end{array}$ & $\begin{array}{l}\text { Retrospective singe center } \\
\text { review November } 1997- \\
\text { March } 1998\end{array}$ & $\begin{array}{l}\text { Death review of potential donors. } \\
\text { Elderly non-traumatic ICH } \\
\text { patients with no mechanical } \\
\text { ventilator support who could } \\
\text { have been potential donors had } \\
\text { they been ventilated }\end{array}$ & $\begin{array}{l}\text { Group A: spontaneous ICH patient who died during } 5 \text { days of review due to } \\
\text { neurologic impairment } \\
\text { Group B: those who were alive or died from non-neurologic causes during } \\
\text { same period } \\
135 \text { patients reviewed: } 15(11 \%) \text { in Group A and } 120(89 \%) \text { in Group B } \\
13 / 15 \text { Group A patients ( } 86 \%) \text { were in the ED }\end{array}$ & Complete \\
\hline $\begin{array}{l}\text { Le Conte } \\
\qquad \text { et al. } \\
\text { (2012) }\end{array}$ & $\begin{array}{l}\text { Prospective post-hoc cross } \\
\text { sectional survey of } 174 \\
\text { hospitals during 2, 2-month } \\
\text { periods in } 2004 \text { and } 2005\end{array}$ & $\begin{array}{l}\text { Potential organ donors dying in ED } \\
\text { with cardiac function }\end{array}$ & $\begin{array}{l}174 / 2420 \text { patients }(7.2 \%) \text { of all patients dying in the ED could have been } \\
\text { potential organ donors }\end{array}$ & Complete \\
\hline
\end{tabular}


Table 3. Summary of papers for successful donation after circulatory determination of death donors

\begin{tabular}{|c|c|c|c|c|}
\hline Paper & Design & Inclusion/exclusion & Outcomes & STROBE checklist \\
\hline Alarhyem et al. (2017) & $\begin{array}{l}\text { Retrospective single center chart } \\
\text { review level I trauma center Jan } \\
2001 \text { - Dec } 2014\end{array}$ & $\begin{array}{l}\text { Trauma patients presenting with } \\
\text { no signs of life }\end{array}$ & $\begin{array}{l}340 \text { patients, } 7 \text { survived } \\
\text { Of } 333 \text { remaining } 12(3.6 \%) \text { donated major organs. } \\
24 \text { organs donated ( } 16 \text { kidneys, } 2 \text { hearts, } 4 \text { livers, } 2 \text { pairs } \\
\text { lungs) } \\
\text { Average } 2 \text { organs per donor }\end{array}$ & Complete \\
\hline Love et al. (2016) & $\begin{array}{l}\text { Retrospective single center chart } \\
\text { review at a level I trauma center } \\
\text { January 1, 2010 - December 31, } \\
2012\end{array}$ & $\begin{array}{l}\text { Adult patients requiring } \\
\text { resuscitation for TCPA, eligibility } \\
\text { assessed after arrival to ED }\end{array}$ & $\begin{array}{l}5 / 237 \text { patients with TCPA successful donors ( } 5 \% \text { ) } \\
11 \text { patients had ROSC and underwent evaluation for organ } \\
\text { donation, organs procured from } 5 \text { patients } \\
1 \text { heart, } 5 \text { livers, } 8 \text { kidneys, } 2 \text { pancreata } \\
\text { Donation rate } 3.2 \text { organs per donor }\end{array}$ & Complete \\
\hline Raoof et el. (2011) & $\begin{array}{l}\text { Retrospective single center chart } \\
\text { review at level I Trauma center } \\
\text { April } 2007 \text { - March } 2010\end{array}$ & All patients who sustained TCPA & $\begin{array}{l}252 \text { patients } \\
39(15.5 \%) \text { survived } \\
19 / 213(8.9 \%) \text { patients who died became organ donors } \\
15 \text { kidneys, } 6 \text { livers, } 4 \text { hearts, } 1 \text { pancreas, } 1.37 \text { organs per } \\
\text { donor } \\
64.7 \% \text { of patients who did not become donors had cardiac } \\
\text { arrest after referral but before organ donor network } \\
\text { arrival } \\
\text { Donation requested for only } 136 / 213 \text { patients }(63.8 \%)\end{array}$ & Complete \\
\hline Summers et al. (2014) & $\begin{array}{l}\text { Prospective audit of all deaths in } \\
\text { the UK from April } 2010 \text { - } \\
\text { December } 2011 \text { grouped into } 9 \\
\text { different zones }\end{array}$ & $\begin{array}{l}\text { All patients who died in a critical } \\
\text { care setting to } \\
\text { Successful kidney donors }\end{array}$ & $\begin{array}{l}\text { 3050/27,482 (11\%) of deaths in ED } \\
43 / 984(4 \%) \text { DBD donors } \\
\text { 24/544 (4\%) were DCD donors } \\
\text { Total: } 67 / 1528(4.4 \%)\end{array}$ & Complete \\
\hline $\begin{array}{l}\text { Gerstenkorn et al. } \\
\text { (2003) }\end{array}$ & $\begin{array}{l}\text { Single center review March } 1995 \text { - } \\
\text { June } 2001\end{array}$ & $\begin{array}{l}\text { Review of all DCD kidney donors } \\
\text { from the accident and } \\
\text { emergency department or ICU }\end{array}$ & $\begin{array}{l}41 \text { DCD kidneys } \\
8 \text { from ED, } 2 \text { successful }(4.9 \%)\end{array}$ & $\begin{array}{l}\text { Did not specify } \\
\text { whether study } \\
\text { was prospective } \\
\text { or retrospective }\end{array}$ \\
\hline DeVita et al. (2016) & $\begin{array}{l}\text { Prospective study at } 2 \text { hospitals } \\
\text { Feb } 2009 \text { - June } 2010\end{array}$ & $\begin{array}{l}\text { Patients with pre-existing donor } \\
\text { designation who received CPR, } \\
\text { failed to respond, pronounced } \\
\text { dead, underwent in-ED } \\
\text { cannulation for organ donation }\end{array}$ & $\begin{array}{l}18 \text { patients potential candidates, } 6 \text { responses triggered, } 2 \\
\text { underwent in-ED cannulation, } 4 \text { organs recovered ( } 3 \\
\text { kidney and } 1 \text { liver) } \\
\text { Time from trigger to perfusion } 14-22.3 \text { minutes } \\
\text { No organs transplanted due to prolonged warm time }\end{array}$ & Complete \\
\hline
\end{tabular}




\section{Table 4. Summary of papers for missed and potential donation after circulatory determination of death donors}

Paper Design Inclusion/exclusion

\section{Halpern et al. Population-based cohort study} (2013) among randomly selected sample of 50 acute care hospitals in the highest volume donor areas in United States from July 1, 2008 - June 30 2009

Campbell et al. Retrospective single center chart (1999) review January 1, 1995 December 31, 1995

Death review of potential kidney

209 patients died in ED and ICU

STROBE checklist

All potentially eligible donors dying 130 potential controlled (52 optimal, 78 suboptimal) DCD donors Randomly selected within 90 minutes of withdrawal $3(2.3 \%)$ died in ED of life-sustaining therapy sample could

increase selection bias

for brain death and experienced

cardiopulmonary arrest after $\quad 3 / 17(18 \%)$ controlled DCD donors seen only in the ED

withdrawal of ventilator support

Daemen et al. Retrospective single center death review in 1994

Potential non-heart beating kidney

after admission to ED screened, 8 potential brain dead heart beating donors

medical suitability scores $\quad 56$ non-heart beating donors (7 low, 22 moderate, 27 high

assigned to give low, moderate, potential)

or high potential group 20/56 (36\%) died in ED

All potential non-heart beating 83 potential NHB donors

donors who died in the ICU and $62(75 \%)$ died in the ED

ED broken down into NHB $\quad 23 / 23(100 \%)$ Category 1 donors

category (1-4)

$37 / 37(100 \%)$ Category 2 donors

$2 / 22(9 \%)$ Category 3 donors

$0 / 1(0 \%)$ Category 4 donors

Blackstock et al. Retrospective single center chart $(2010)$ review 2004-2008

All patients who underwent tracheal intubation in ED who

1166 patients died in ED

Complete were not admitted to ICU, then underwent extubation in the ED and died within 2 hours

Aubrey et al. Retrospective study at 10 accident Death audit of potential heart

770/1204 deaths audited

Complete

$6(0.5 \%)$ potential $\mathrm{DCD}$

Complete

beating and controlled non-heart 20 potential solid organ donors (16 retrospective, 4 prospective) UK October 2004 - December beating donors on a ventilator 14 potential heart beating $(2 \%)$ and $2(0.3 \%)$ potential non-heart 2005

beating donors died in the ED

Complete

All patients who sustained TCPA

$64.7 \%$ of patients who did not become donors had cardiac arrest Complete

after referral but before organ donor network arrival

Donation requested for only $136 / 213$ patients (63.8\%)

$\mathrm{DCD}=$ Donation after circulatory determination of death; $\mathrm{ED}=$ emergency department; $\mathrm{ICU}=$ intensive care unit; $\mathrm{NDD}=$ neurologic determination of death; $\mathrm{ROSC}=$ return of spontaneous circulation; $\mathrm{TCPA}=$ traumatic cardiopulmonary arrest. 


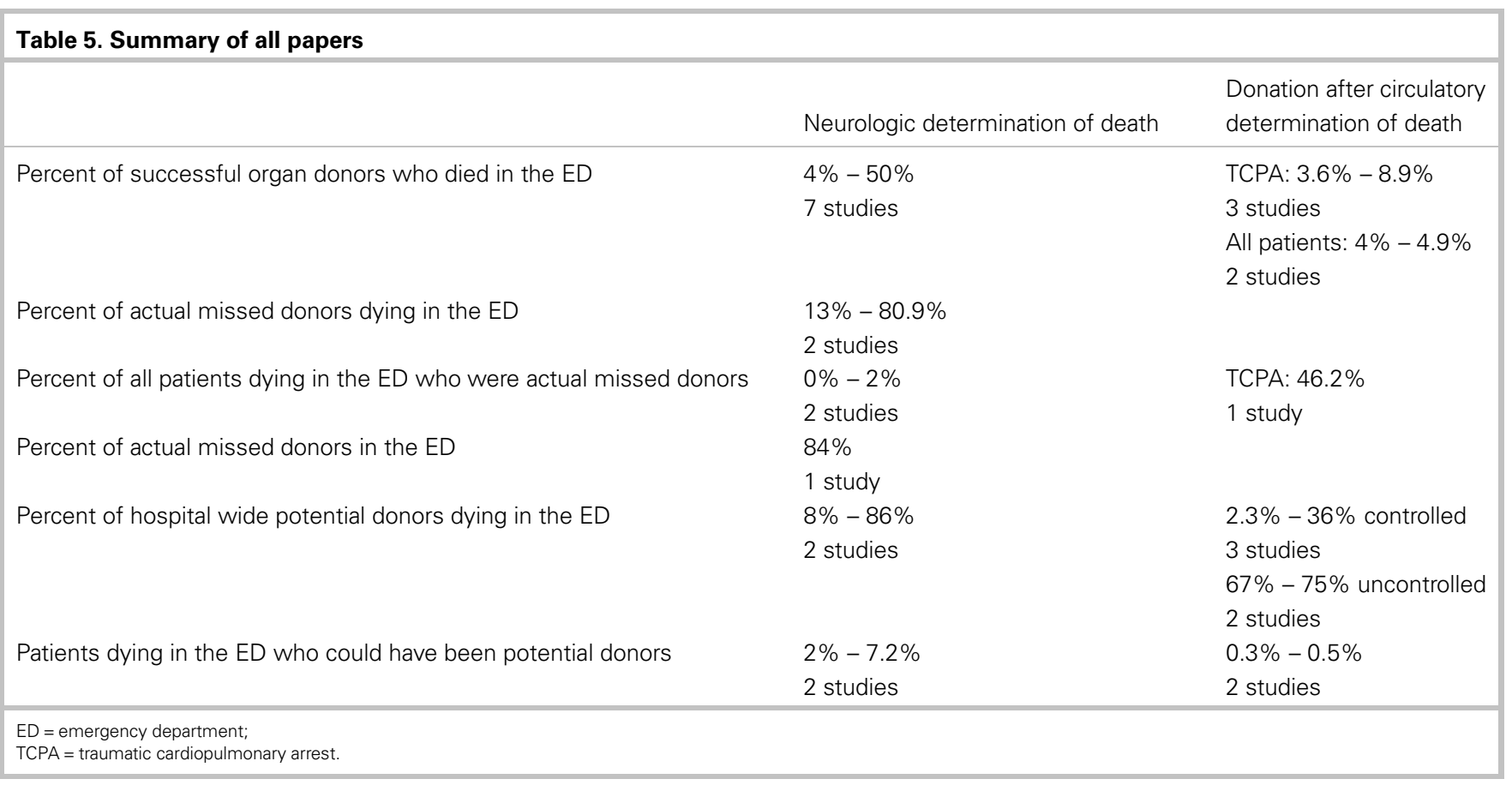

There were four death reviews that screened for potential organ donors using pre-specified organ donor criteria; however, the criteria varied between studies or was not specified in the paper. ${ }^{22-25}$ Two studies found that $8 \%-86 \%$ of hospital-wide potential donors die in the ED. ${ }^{22,23}$ Two studies found that $2 \%-7.2 \%$ of patients who die in the ED could be potential donors. ${ }^{24,25}$ A summary of these papers can be found in Table 2 .

One study investigated all spontaneous intracerebral hemorrhage patients to determine how many potential donors were not approached due to not being ventilated. ${ }^{23}$ They found that $12 / 15(86 \%)$ of these patients died in the $\mathrm{ED}^{23}$ The authors of this study highlighted the ethical considerations in ventilating a person exclusively for organ donation.

\section{Donation after circulatory determination of death}

There were six studies that described successful donation after circulatory determination of death. ${ }^{26}$ All six studies involved an organ procurement organization or coordinator in the donation process. Three studies investigated patients with traumatic cardiopulmonary arrest who achieved return of spontaneous circulation and went on to become organ donors. Alarhyem et al. found that $12 / 333$ (3.6\%) donated 24 major organs. ${ }^{26}$ Love et al. (2016) found that 5/237 (2\%) patients donated 16 major organs. ${ }^{27}$ Raoof et al. (2011) found that $19 / 213$ $(8.9 \%)$ donated 26 major organs. ${ }^{28}$ Taken together, $3.6 \%-8.9 \%$ of traumatic cardiopulmonary arrest patients dying in the ED become successful organ donors. Two studies reviewed successful kidney donation specifically. Summers et al. (2014) found that 67/ $1528(4 \%)$ of successful donors (neurologic determination of death and donation after circulatory determination of death) died in the ED and 24/544 (4\%) of the donation after circulatory determination of death donors came from the ED. ${ }^{15}$ Another study found that 8/41 kidneys came from patients dying in the ED, with $2 / 41$ (4.9\%) successfully transplanted. ${ }^{29}$ These studies suggest that $4 \%-4.9 \%$ of successful donations after circulatory determination of death kidney donors come from the ED. One study investigated the use of in-ED cannulation for uncontrolled donation after circulatory determination of death. There were 18 potential candidates, and four organs were recovered (three kidneys and one liver). There were no organs transplanted due to prolonged warm time, but, as technology advances, this could improve in the future. ${ }^{30}$ A summary of successful donation after circulatory determination of death donors can be found in Table 3 .

There was one death review in traumatic cardiopulmonary arrest that investigated actual missed organ donors who died in the ED and were missed donors as a result of a 
failure to refer for consideration of organ donation. ${ }^{28}$ This study reported that $46.2 \%$ of traumatic cardiopulmonary arrest patients dying in the ED were not referred.

There were six death reviews that screened for potential donation after circulatory determination of death donors, using pre-specified criteria; however, the criteria varied between studies. ${ }^{11,25,31-34}$ Three death reviews investigated potential controlled donation after circulatory determination of death donors hospital-wide and found that $2.3 \%-3.6 \%$ died in the ED. ${ }^{11,31,32}$ Similarly, two death reviews investigated potential uncontrolled donation after circulatory determination of death donors hospital-wide and found that $67 \%-75 \%$ died in the ED. ${ }^{31,33}$ Two death reviews investigated all patients dying in the ED and found that $0.3 \%-0.5 \%$ of them could be potential donors. ${ }^{25,34}$ A summary of missed and potential donation after circulatory determination of death donors can be found in Table 4 .

\section{Factors associated with successful and missed organ donation}

Several studies investigated factors associated with successful organ donation (Tables 1-4). One study found that successful organ donation was associated with a referral from the ED instead of inpatient. ${ }^{7}$ There was also an insignificant trend towards ED referrals being more likely to have consent granted compared with inpatient settings. ${ }^{7}$ When compared with patients referred from the ICU, patients referred from the ED were more likely to become actual organ donors, and the total organs donated had a trend towards being higher. ${ }^{6}$ Two studies investigated education programs, including an on-call transplant coordinator or nurse and found they increased organ donation. ${ }^{17,19}$ Three studies included in this review investigated specific reasons why potential organ donors are missed. One study found the main reasons that organ donation was not discussed were that the treating physician forgot $(23 / 72)$, the incorrect assumption that the patient was too old (11/72), or the incorrect assumption that the patient was not suitable as an organ donor (7/72). Similarly, another study found that out of 19 charts with patients documented as "medically unsuitable" for organ donation, only 3 were actually medically unsuitable. ${ }^{21}$ Perceived barriers cited by healthcare staff included non-recognition as an organ donor, lack of confidence in offering organ donation, no contact for transplant coordinator, shortage of ICU beds, coroner involvement, and limited resources. ${ }^{25}$

\section{DISCUSSION}

\section{Interpretation}

This systematic review investigated what percent of actual, missed, and potential organ donors come from the ED (Table 5). We demonstrated that the ED is a source of successful organ donors; patients referred from the ED are more likely to become successful donors, and they donate more organs than patients referred from elsewhere in the hospital (Tables 1 and 2). We also found that a significant proportion of patients die in the ED without exploring the possibility of organ donation and are often missed as donors due to a failure to refer for consideration of organ donation (Tables 3 and 4). Several themes emerged regarding why potential donors are missed. The most common were inaccurate assumptions regarding inclusion criteria and forgetting to refer the patient. All seven papers describing successful neurologic determination of death and all six papers describing successful donation after circulatory determination of death highlighted the importance of involving an organ procurement organization or coordinator in the donation process. The role of the ED healthcare team is predominantly in referral for consideration of organ donation to the organ donation organization or coordinator.

\section{Comparison to previous systematic reviews}

Several systematic reviews have been conducted on organ donation previously; however, they describe techniques of organ extraction, discuss techniques to increase likelihood of successful donation, or pool all acute areas of the hospital. ${ }^{9,10,35}$ The strength of this systematic review is that it is the first that we are aware of to investigate organ donation in ED patients specifically.

\section{Limitations}

There are several limitations to this systematic review. The studies had heterogeneous populations, used different inclusion criteria for organ donors, or did not mention their criteria, precluding a meta-analysis. There is a very large range in percentages of successful and missed donors in the studies, and it is difficult to draw meaningful conclusions on why these large ranges exist based on the data in the studies. Many of these factors impacting rates of donation may be out of the realm of the ED. Studies investigating missed or potential donors do not reflect on how many 
of each of those donors would be lost in the consent process, procurement process, or transplantation process, so the numbers of potential donors would be lower than reported. In addition, most of the studies included in this review were retrospective and are limited by the biases associated with conducting a retrospective study.

\section{Clinical implications}

Inaccurate assumptions regarding inclusion criteria and medical suitability can be addressed by involving an organ donation coordinator, organ donation nurse, or organ procurement organization involved early in the dying process. ${ }^{26}$ The role of the ED in many of the successful organ donation studies was in timely referral to the organization or coordinator. Involving a separate organization also removes some of the conflict of interest and ethical dilemma placed on the ED to simultaneously provide patient care and discuss organ donation. ${ }^{6}$ Recent Canadian guidelines have been developed regarding the process of consent and approaching families. ${ }^{36}$ The role of the physician is to ensure that the organ procurement organization has been contacted. These guidelines also recommend the healthcare team involved in patient care not approach the family regarding organ donation until an organ donation organization has been contacted. They suggest that any family meetings involve the donor coordinator, primary bedside nurse, and most responsible treating physician. It is clear that a multi-disciplinary approach is essential when discussing organ donation.

Resource utilization was another ethical dilemma identified in this systematic review. Although it seems intuitive that ICU admission for organ donation is costly, Melville et al. (2017) found that patients transferred to the ICU for consideration of organ donation did not use disproportionate resources when compared with patients transferred for palliative care. ${ }^{37}$ This perceived boundary should not prevent referral of dying patients to an organ procurement organization.

\section{Research implications}

Several knowledge gaps exist in organ donation from the ED. Future research should determine the optimal education curriculum to overcome misconceptions regarding organ donation. Also, the optimal timing of organ donation discussions during resuscitations should be elucidated. The feasibility and impact of uncontrolled donation after circulatory determination of death and donation in conjunction with Extracorporeal membrane oxygenation (ECMO) and Resuscitative endovascular balloon occlusion of the aorta (REBOA) are other areas of future research.

\section{CONCLUSION}

In conclusion, the ED is a source of actual and missed donors. Potential donors are often missed due to incorrect assumptions regarding eligibility criteria and failure of the healthcare team to refer patients for consideration of donation. Early incorporation of an organ procurement organization increases successful donation. ED healthcare professionals should be aware of the organ donation referral process at their institution to ensure that no organ donors are missed.

Acknowledgements: We would like to thank librarians Risa Shorr and Johanne Gohier for their assistance with the search criteria and obtaining the papers.

Presentation: This study was presented at the Canadian Association of Emergency Physicians (CAEP) 2018 on May 28, 2018.

Financial support: Funding to pull three articles (\$39) was obtained from the Department of Emergency Medicine. Funding for presentation at CAEP was provided by the Department of Emergency Medicine in Ottawa.

Dr. Stiell holds a Distinguished Professorship and University Health Research Chair from the University of Ottawa.

Author contributions: JM was responsible for the study concept and design, acquisition of data, analysis and interpretation of data, drafting of manuscript, critical revision of the manuscript important for intellectual content, and data analysis. BE was responsible for the acquisition of data, critical revision of the manuscript important for intellectual content, and data analysis. SD was responsible for the study design and critical revision of the manuscript important for intellectual content. IS was responsible for the study concept and design, critical revision of the manuscript important for intellectual content, data analysis, and acquisition of funding.

Competing interests: None declared.

\section{SUPPLEMENTARY MATERIAL}

The supplementary material for this article can be found at https://doi.org/10.1017/cem.2019.365

\section{REFERENCES}

1. Trillium Gift of Life Network - Ontario's Organ and Tissue Donation Agency: public reporting; 2018. Available at: https://www.giftoflife.on.ca/en/publicreporting.htm (accessed September 15, 2018). 
2. Quick facts on organ donation and organ donation and transplant in BC transplant in BC; 2019. Available at: http://www.transplant.bc.ca/health-info/organ-donationtransplant-statistics (accessed February 23, 2019).

3. Witjes M, Kotsopoulos A, Herold IHF, et al. The influence of end-of-life care on organ donor potential. Am 7 Transplant 2017;17(7):1922-7.

4. Fernandes-Carmona A, Sevilla-Martinez M, PérezVillares JM, et al. Donation interview before to brain death. Intensive Care Med 2015;3 (Suppl 1):A903.

5. Tenn-Lyn NA, Doig CJ, Shemie SD, et al. Potential organ donors referred to Ontario neurosurgical centres. Can 7 Anaesth 2006;53(7):732-6.

6. Miller LD, Gardiner SK, Gubler KD. Emergency department referral for organ donation: more organ donors and more organs per donor. Am 7 Surg 2014;207(5):728-33, discussion 733-4.

7. Michael GE, O'Connor RE. The importance of emergency medicine in organ donation: successful donation is more likely when potential donors are referred from the emergency department. Acad Emerg Med 2009;16(9):850-8.

8. Cameron A, Erdogan M, Lanteigne S, et al. Organ donation in trauma victims. 7 Trauma 2018;84(6):994-1002.

9. Squires JE, Coughlin M, Dorrance K, et al. Criteria to identify a potential deceased organ donor. Crit Care Med 2018;46 (8):1318-27.

10. Van Erp AC, van Dullemen LFA, Ploeg RJ, Leuvenink HGD. Systematic review on the treatment of deceased organ donors. Transplant Rev 2018; epub.

11. Halpern SD, Hasz RD, Abt PL. Incidence and distribution of transplantable organs from donors after circulatory determination of death in U.S. Intensive Care Units. Annals ATS 2013;10(2):73-80.

12. Moher D, Liberati A, Tetzlaff J, Altman DG; PRISMA Group. Preferred reporting items for systematic reviews and meta-analyses: the PRISMA statement. Ann Intern Med 2009;151:264-9, W64.

13. Thuong M, Ruiz A, Evrard P, et al. New classification of donation after circulatory death donors definitions and terminology. Transpl Internat 2016;29(7):749-59.

14. Elm von E, Altman DG, Egger M, et al. The Strengthening the Reporting of Observational Studies in Epidemiology (STROBE) statement: guidelines for reporting observational studies. PLoS Med 2007;4:e296.

15. Summers DM, Johnson RJ, Hudson AJ, et al. Standardized deceased donor kidney donation rates in the UK reveal marked regional variation and highlight the potential for increasing kidney donation: a prospective cohort study. Brit 7 Anaesth 2014;113(1):83-90.

16. Ergin M, Karaman L, Demircan A, Dalgiç A. Potential organ donor concept is developing in emergency departments: Gazi University hospital experience. Transpl P 2008;40(1):39-41.

17. Henderson SO, Chao JL, Green D, et al. Organ procurement in an urban level I emergency department. YMEM 1998;31 (4):466-70.

18. Dell Agnolo CM, de Freitas RA, Toffolo VJO, et al. Causes of organ donation failure in Brazil. Transpl P 2012;44 (8):2280-2.
19. Garside J, Garside M, Fletcher S, Finlayson B. Utilisation of an embedded specialist nurse and collaborative care pathway increases potential organ donor referrals in the emergency department. Emerg Med 7 2012;29(3):228-32.

20. Broomberg CJ, McCurdie FJ, Kahn D. Prospective audit of deaths at a teaching hospital. Transpl P 2005;37(2):556-7.

21. Riker RR, White BW. Organ and tissue donation from the emergency department. 7 Emerg Med 1991;9(6):405-10.

22. Kim SC, Kim TH, Jang HJ, et al. Potential organ donor pool for renal transplantation in the intensive care unit and emergency room. Transpl P 2000;32(7):1567-8.

23. Andrés A, Sánchez Casado M, Cebrián P, et al. Very old patients with spontaneous cerebral hemorrhage are an important group of potential organ donors. Transpl P 1999;31(6):2593-4.

24. Le Conte P, Riochet D, Labastire L, et al. Identification of potential organ donors of advanced age in EDs. Am 7 Emerg Med 2012;30(1):170-3.

25. Aubrey P, Arber S, Tyler M. The organ donor crisis: the missed organ donor potential from the accident and emergency departments. Transpl P 2008;40(4):1008-11.

26. Alarhayem AQ, Cohn SM, Muir MT, et al. Organ donation, an unexpected benefit of aggressive resuscitation of trauma patients presenting dead on arrival. $7 \mathrm{Am}$ Coll Surg 2017;224(5):926-32.

27. Love KM, Brown JB, Harbrecht BG, et al. Organ donation as an outcome of traumatic cardiopulmonary arrest. 7 Trauma 2016;80(5):792-8.

28. Raoof M, Joseph BA, Friese RS, et al. Organ donation after traumatic cardiopulmonary arrest. AFS 2011;202(6):701-6.

29. Gerstenkorn C. Non-heart-beating donors: renewed source of organs for renal transplantation during the twenty-first century. World 7 Surg 2003;27(4):489-93.

30. DeVita MA, Callaway CW, Pacella C, et al. Experience with a new process - Condition $\mathrm{T}$ - for uncontrolled donation after circulatory determination of death in a university emergency department. Prog Transpl 2016;26(1):21-7.

31. Campbell GM, Sutherland FR. Non-heart-beating organ donors as a source of kidneys for transplantation: a chart review. CMA7 1999;160(11):1573-6.

32. Daemen JW, Oomen AP, Kelders WP, Kootstra G. The potential pool of non-heart-beating kidney donors. Clin Transplant 1997;11(2):149-54.

33. Lacroix JD, Mahoney JE, Knoll GA. Renal transplantation using non-heart-beating donors: a potential solution to the organ donor shortage in Canada. Can F Surg 2011;47(1):10-4.

34. Blackstock M, McKeown DW, Ray DC. Controlled organ donation after cardiac death: potential donors in the emergency department. Transplantation 2010;89(9):1149-53.

35. Sandroni C, D'Arrigo S, Callaway CW, et al. The rate of brain death and organ donation in patients resuscitated from cardiac arrest: a systematic review and meta-analysis. Intensive Care Med 2016;42(11):1661-71.

36. Shemie SD, Robertson A, Beitel J, et al. End-of-life conversations with families of potential donors. Transplantation 2017;101:S17-26.

37. Melville A, Kolt G, Anderson D, et al. Admission to intensive care for palliative care or potential organ donation. Crit Care Med 2017;45(10):e1050-9. 